\title{
TACR3 wt Allele
}

National Cancer Institute

\section{Source}

National Cancer Institute. TACR3 wt Allele. NCI Thesaurus. Code C51480.

Human TACR3 wild-type allele is located within $4 \mathrm{q} 25$ and is approximately $130 \mathrm{~kb}$ in length. This allele, which encodes neuromedin $\mathrm{K}$ receptor protein, plays a role in the modulation of receptor interactions involving the neuropeptide tachykinin. 